\title{
A Systems Dynamics Model To Analyze The Influence Of Financial Resources On The Percentage Of Franchised Units
}

Rosa Ma Mariz-Pérez, University of La Coruña, Spain

$\mathbf{M}^{\mathrm{a}}$ Teresa García-Alvarez, University of La Coruña, Spain

\begin{abstract}
In this paper, we analyze the evolution of the percentage of franchised units. For this purpose, the sample includes Spanish chains that were already franchising in 1997 and continue to do so in 2005 - a nine year period-. Specifically, we study the influence of the availability/constraints of financial resources on the decision of the franchisor to invest in an additional chain unit or to franchise it. For this, we develop a simulation model using the Systems Dynamics methodology.
\end{abstract}

Keywords: franchising, financial resource constraints, systems dynamics

\section{INTRODUCTION}

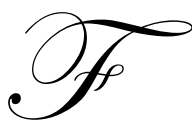

ranchised chains constitute hybrid organizational forms because they share characteristics of both extreme solutions. In business-format franchising, it is common to observe that the franchisor is the owner of some units -usually the larger ones-, while other outlets belong to franchisees. Therefore, in some cases, chains rely on central planning and, in others, on advantages of powerful incentives. Far from establishing superiority of one organizational form over another many studies have highlighted that the presence of both types of outlets has important complementary and synergetic effects (Dant et. al., 1996; Bradach, 1998; Cliquet, 2000; Pénard et. al., 2003; Yin \& Zajac, 2004).

As franchising has become a relevant activity in developed economies, it has received an important portion of the attention of researchers. In this sense, many papers have attempted to analyze the proportion of franchised units and explain the factors that determine why, in some cases and chains, franchising is employed more intensively than in others. One of the most extended reasons is based on the idea that financial constraints lead chains to rely, in greater extent, on franchisees in order to achieve the desired growth rates.

We also address this problem, although our work has significant differences with respect to existing literature. First, we use panel data for a nine year period between 1997 and 2005, while most empirical papers have employed cross-sectional data. Second, our panel is slightly different because it includes chains that were already franchising in 1997 and continue to do so in 2005. Therefore, we analyze successful franchisors. Third, the methodology we apply -Systems Dynamics- allows for a dynamic analysis and is specially indicated for complex cases where relations between the variables are not linear and feedback loops exist. Thus, it seems the appropriate methodology to analyze the percentage of franchised units.

\section{LITERATURE REVIEW}

Different justifications have been provided to explain why businesses choose to expand through franchising and the evolution of the growth pattern they follow. The resource-based view establishes that franchising will be employed, more intensively, by chains in early stages of their life-cycle. This is because young businesses suffer greater problems related to resource constraints - either financial, related to knowledge or managing talent (Oxenfeldt \& Kelly, 1968-1969; Brickley, Dark \& Weisbach, 1991; Thomson, 1992; Sen, 1993, 1998; Dant et al., 
1996; Shane, 1996; Watson et. al., 2005). This means that the franchisor will turn, in greater extent, to expansion of chain through the opening of franchised outlets to reduce his problems of resource restrictions and, in this way, achieve higher growth rates. As the resource constraints are reduced, central offices will not rely on franchising in such an intensive manner as in past phases, and will chose to grow through more franchisor-owned units. Leaving aside intangible assets, financial resources restraints have been one of the most extended reasons to justify the existence and growth of franchising. In this sense, the franchisor may face important financial constraints that do not allow him to open additional outlets directly. In these cases, franchisees provide valuable funds and contribute to boost growth. In this paper, we address this situation and analyze if this type of restrictions can explain the existence of franchising.

However, in order to consider this the basic cause of the existence of franchising, the average cost of these financial resources should be lower than that available to the franchisor through the Capital Market. Moreover, the franchisor may face certain difficulties in order to obtain the necessary funds in capital markets -most of the assets he owns are intangible and, therefore, difficult to value and are subject to high variability. Additionally, young chains can be subject to even mayor difficulties to receive financial resources from external investors and this leads them to depend, more intensively, on franchisees to maintain certain levels of growth. The latter are viewed as an inexpensive source of capital.

However, despite broad acceptance among researchers, the capital constraint explanation for franchising seems at odds with modern financial theory (Rubin, 1978). In this sense, other researches state that expansion through franchised outlets constitutes an expensive option, given the risk premium demanded by risk-adverse franchisees (Rubin, 1978; Brickley, Dark \& Weisbach, 1991). Franchisees face high risk compared to franchisors because their investment is less diversified -the latter has a portfolio of outlets and receives a revenue stream from the royalty, input and initial fees-. Empirical evidence is quite mixed. Results include the existence of higher proportions of franchised units during high-growing phases (Shane, 1996). Thompson (1992) and Sen (1998) have also provided certain evidence to back the capital constraint explanation.

Most researches have reported no evidence in order to accept this hypothesis. Results presented by Brickley (1999), for example, attempt against this type of reasoning and findings include that the probability of direct investment of the franchisor in new outlets is positively related to the amount of the required initial investment. Moreover, it is quite common for the parent firm to provide franchisees with financial assistance. These results can be better explained through risk-aversion of franchisees and not due to financial resource restrictions of franchisors (Lafontaine \& Kaufmann, 1994).

These findings and the fact that franchising is not reduced nor it disappears with time, are at odds with the resource constraints hypothesis that can be announced as follows:

H1: the lower the availability of financial resources, the higher the propensity of the franchisor towards franchising.

\section{METHODOLOGY. SAMPLE AND MODEL}

Given the impossibility to employ a ready-to-use data base, the sample was drawn from the four annual franchising guidebooks published in Spain. The sample includes the nine year period from 1997 and 2005. We also found that it was necessary to conduct different interviews with several franchising experts in order to manage to get other qualitative or "soft" information". The final sample includes 158 Spanish chains that belong to all existing sectors of activity. Given this size, it was only possible to take into account the difference between chains belonging to product or distribution sectors and those dedicated to the provision of services.

\footnotetext{
${ }^{1}$ To be precise, in many occasions, we asked professors Dr. Manuel González Díaz and Dra. Begoña López Fernández from the University of Oviedo and Dr. Luís Vázquez Suárez of the University of Salamanca in Spain for their qualified opinions. As for professionals, we contacted with the President of the Spanish Association of Franchisors, Xabier Vallhonrat, and with various franchisors, consultants and franchisees me at the symposium on franchising celebrated at he University of Oviedo in July 2005.
} 
We have developed a Systems Dynamics model to study the evolution of the proportion of franchised outlets and to identify the factors or variables of influence. The model includes other variables that have been considered as relevant in the literature although, in this case, only the results related to the importance of financial resources are presented. Obviously, all models constitute a simplified representation of the reality or system they describe and to consider them as adequate, they must reproduce the real pattern and serve for the purpose for which they were developed.

For the franchisor, income has two basic sources because both franchised units and franchisor-owned outlets provide financial flows. The first type of outlets supplies the chain with cash-flow liquidity when the franchisee joins the chain -lump sum entry fee- and, later on throughout the life of the outlet, a series of payments due to the establishment of royalties, other contractual periodical rents -both fixed and variable- and the existence of compulsorily purchases. On the other hand, the outlets owned by the franchisor provide a flow of income equal to the level of sales of each unit.

Similarly, the quantity of financial resources the franchisor has is reduced because of various types of costs and/or investments he must undergo. These outflows include operating costs of the outlets he directly owns, total control costs -obtained as the sum of fixed control costs of central offices, total management and supervision costs to be done at each outlet and control costs that are due to the necessity of having area supervisors-, total selection and advisement costs, total opening costs, advertising costs and investments and the membership fees of the Spanish Association of Franchisors -AEF-.

\section{RESULTS}

In order to proceed to model validation, first we graphically compare the real evolution pattern with that obtained as the outcome of the model. In this sense, figures 1 and 2 respectively show the real and simulated evolution of the proportion of franchised outlets for the chains included in the sample. Although the pattern obtained as a result of the model does not exactly reproduce that described by real data, it does adequately represent the same overall evolution.

We can observe that the proportion of franchised outlets grows, more intensively, during the first three or four years of activity and, later on, it tends to stabilize around $80 \%$ for service chains and $70 \%$ for product distribution chains.

Additionally, different tests were performed in order to check for the consistency of the results of the model. The aim is to confirm that model outputs do not contradict logic and franchising literature.

The correlation coefficient provides important information in order to judge the goodness of the model, this is, the degree to which simulated data adjust to real data. To calculate $\mathrm{R}^{2}$ and the other statistical measures, we have used the module developed by Oliva (1995) based on the work of Sterman (1984).

Oliva (1995) proposes model calibration -the process of estimating model parameters (structure) to obtain a match between observed and simulated structures and behaviours- as a form of model testing. For this purpose, the mean square error (MSE) between simulated and actual series is decomposed into three components (Theil, 1966): bias, unequal variation and unequal covariation. Dividing each component by the MSE gives the fraction of the error that is due to unequal means, unequal variances and unequal covariation.

Table 1 shows the value of the different statistical measures that help to determine if simulated data adequately fits real data and if differences are due to errors in the model or to high randomness of actual data. The analysis is done, independently, for the two types of chains included -service and product distribution-. Overall, results indicated that adjustment is better for service chains; the sample only includes 68 product distribution chains that entail high heterogeneity. For both sectors of activity $\mathrm{R}^{2}$ is over $91 \%$. 


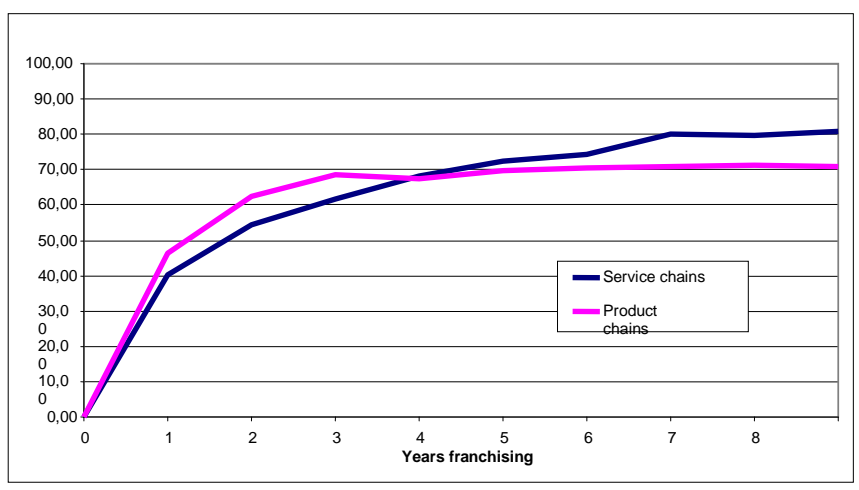

Figure 1: Evolution of the real percentage of franchised units

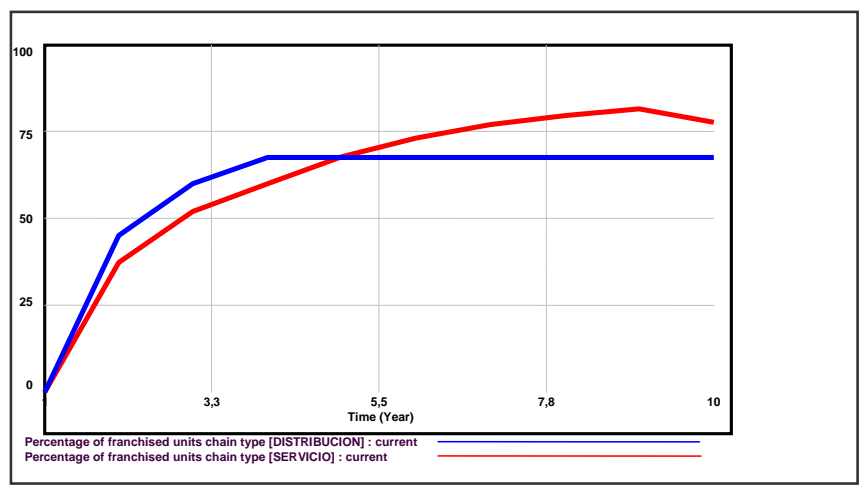

Figure 2: Evolution of the simulated percentage of franchised units

Table I: Statistical validation results

\begin{tabular}{|c|c|c|}
\hline & Services & Distribution \\
\hline Correlation coefficient $\left(\mathbf{R}^{2}\right)$ & 0.9653 & 0.9148 \\
\hline Mean square error (MSE) & 5,959 & 14,001 \\
\hline Root mean square error (RMSE) & 2,441 & 3,741 \\
\hline Root mean square error percentage (RMSEPE) & 0,0336 & 0,0539 \\
\hline $\operatorname{Bias}\left(\mathbf{U}^{\mathrm{m}}\right)$ & 0,1389 & 0,1851 \\
\hline Unequal Variation $\left(\mathbf{U}^{\mathrm{s}}\right)$ & 0,0339 & 0,0069 \\
\hline Unequal Covariation $\left(\mathbf{U}^{\mathrm{c}}\right)$ & 0,8271 & 0,8078 \\
\hline
\end{tabular}

The greatest portion of error is due to the third component - unequal covariation- and, therefore, differences between simulated and real data are mostly due to covariation matters. In this sense, results indicated that although the model does not exactly reproduce the actual value of the proportion of franchised units, it does adequately reflect the mean values and the dominant tendencies in each time period. Therefore, the error is small and non systematic and the model is useful for explaining system behaviour.

Although the model does not reproduce the real observed pattern in an exact manner, its evolution is fairly similar and model calibration shows that it is useful to explain the proposed problem. In order to analyze the influence of financial resources of the franchisor over the proportion of franchised outlets, we have studied how the latter changes when variations are taken in three of the relevant variables identified in the literature: quantity of the initial investment the franchisee must undertake, quantity of the initial financial resources the franchisor has and the investment premium of the franchisor to open a unit directly. As for the first of these variables, we analyze model 
sensibility to changes in this parameter with values between 3.000 and 700.000 euros and intermediate simulations each 10.000 euros. Results are presented in figures 3 and 4.

Results highlight that when the initial investment the franchisee must make is reduced, the attractiveness of chain's contractual conditions increases and this, in turn, increases the availability of new potential franchisees willing to join the chain. So, if the franchisor decides that the best option is to franchise the new outlets, there will be more opportunities for opening these franchised units because the availability of prospective franchisees will not limit growth. However, this barely increases the proportion of franchised outlets for service chains, while those belonging to the product distribution sector are a little more sensitive to lower quantities of initial investment.

Symmetrically, if the quantity of the initial investment increases, the availability of potential franchisees is reduced and the chain must grow, in greater extent, through franchisor-owned outlets. Results indicate that from period 15, when chain attractiveness increases due to chain size, the percentage of franchised outlets rises again. This is because the higher number of chain outlets has a relevant positive effect over brand name recognition and this, logically, increases the number of potential franchisees willing to join the chain, specially for the service sector.

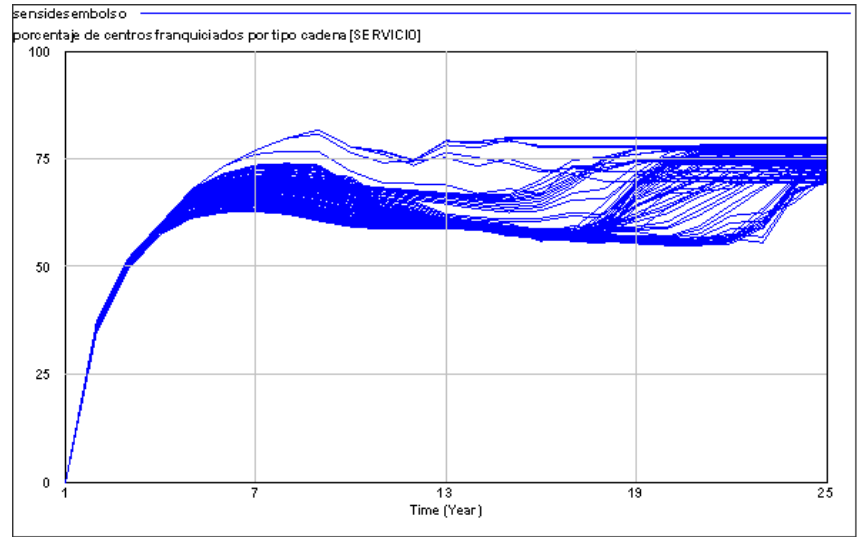

Figure 3: sensibility analysis to the quantity of initial investment (service chains)

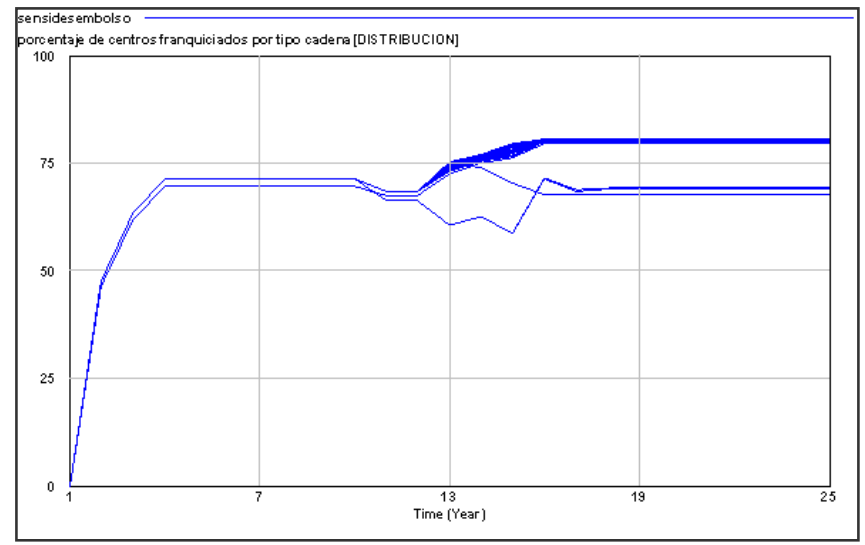

Figure 4: Sensibility analysis to the quantity of initial investment (product chains)

These results are in contradiction with the financial resource scarcity proposition, so more powerful reasons must exist to explain the use of franchising. Thus, we do not obtain sufficient evidence to support the resource constraints hypothesis. Nevertheless, although higher initial investment do not lead to increases franchising activity, 
it can be possible to find that chains with lower financial resources employ franchising more intensively.

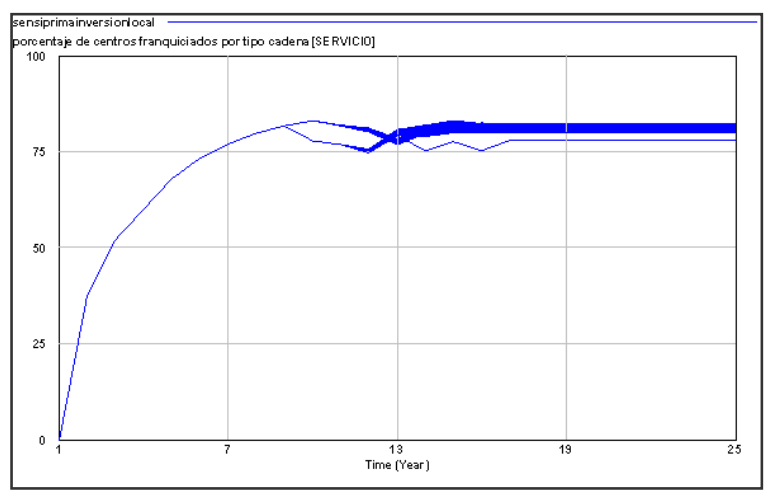

Figure 5: Sensibility analysis to the quantity of the investment premium (service chains )

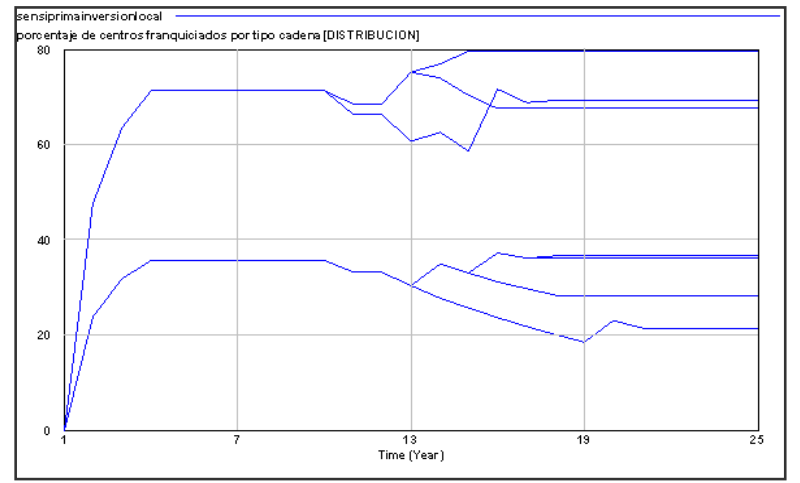

Figure 6: Sensibility analysis to the quantity of the investment premium (product chains)

Product distribution chains are considerably more sensitive to changes in the quantity of the investment premium the franchisor must undergo to open an outlet of his property. This is observed in figures 5 and 6 . The analysis has been done taking values between 0 and 300.000 euros with intermediate simulations every 1.000 euros.

When this premium is reduced to zero, the advantages of franchising for service chains remain, practically the same, while for product distribution chains, franchised outlets become less attractive for the franchisor. So, franchising in this case is reduced. Symmetrically, if the premium increases, advantages of franchised outlets also increase and this will power the decision to franchise and, therefore, the percentage of franchised outlets. It must be taken into account that these results only occur when values are near the extreme values tested.

Related to the above, we thought that it would also be relevant to test for sensitivity of the model to changes in the quantity of initial financial resources of franchisors. In this sense, the response of the model to changes in the quantity of financial resources available, necessary investment premium and initial franchisee investment will help to test the resource scarcity hypothesis.

To analyze the influence of changes in initial financial resources, we used intermediate simulations every 200.000 euros between a minimum of 60.000 and a maximum of 20.000 .000 euros. Results are presented in figures 7 and 8 and, overall, we can say that the proportion of franchised outlets does not vary with changes in the quantity of franchisor financial resources. 


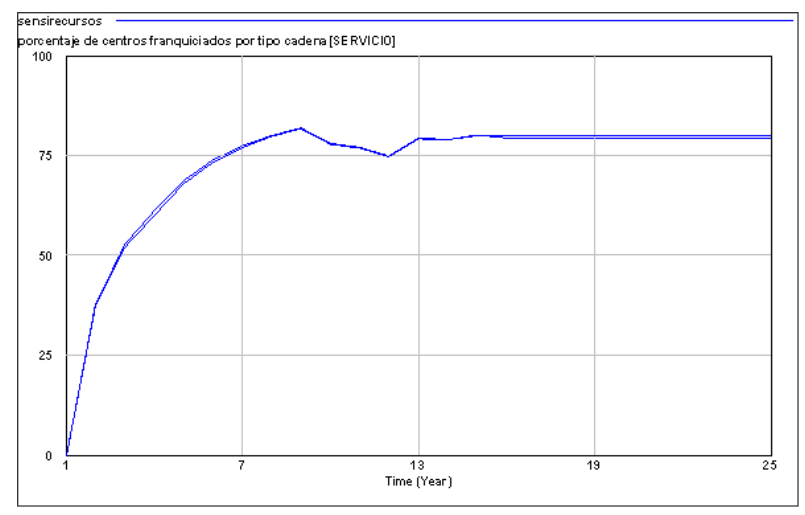

Figure 7: sensibility analysis to the initial financial resources (service chains)

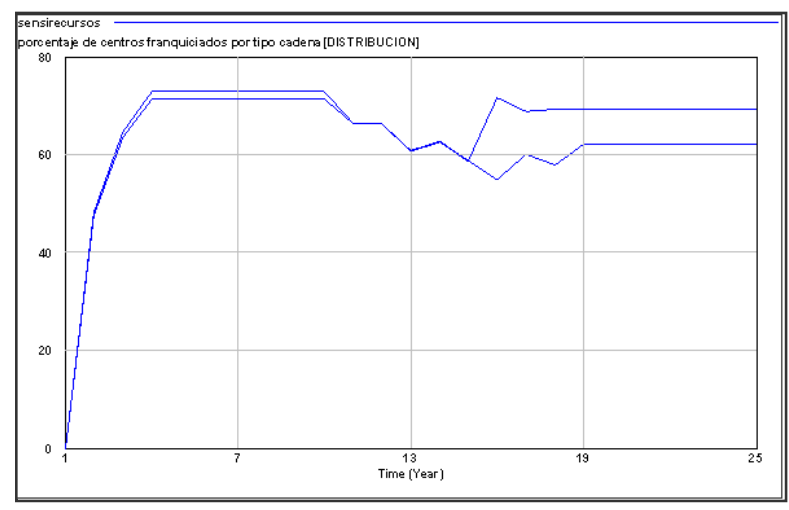

Figure 8: Sensibility analysis to the initial financial resources (product chains)

If these resources are reduced, service chains do not exhibit any response at all while product distribution chains slightly increase the proportion of franchised outlets. In exchange, if availability of financial resources increases, the percentage of franchised units does not increase for both types of chains.

Therefore, given the above results, globally we do not obtain sufficient evidence to accept the null hypothesis for the case of service chains. However, if we take into account the sensibility of the proportion of franchised outlets of product distribution chains due to changes in the investment premium, it seems that the availability of financial resources does help to explain ownership in this type of sectors of activity. A possible explanation to these findings may be that the remaining advantages or motivations for franchising do not have the importance they have within services, so the quantity of this investment premium gains relevance.

\section{CONCLUSIONS}

In this paper we study if the availability or scarcity of franchisor financial resources can help to explain the franchising decision. With this purpose, a simulation model, using the Systems Dynamics methodology is constructed to test the financial resource constraints hypothesis. This methodology is adequate because it allows taking into account the existing interrelations within the key variables and the presence of non linearity in these relations and delays. 
Results indicate that this type of resources have a reduced effect over the evolution of the proportion of franchised outlets, especially in the case of service chains. We do not obtain sufficient evidence to accept the stated hypothesis and, therefore, other mayor motivations or advantages for franchising must come from other sources. Within these, we will continue efforts to analyze the influence of risk distribution, control or monitoring costs, motivation or restrictions that affect other type of relevant resources, especially the intangible ones. This may contribute, in greater extent, to explain the percentage of franchised outlets of this type of hybrid organizational form.

\section{AUTHOR INFORMATION}

Rosa $\mathbf{M}^{\mathbf{a}}$ Mariz-Pérez is a Assistant Professor in Business Organization at the University of La Coruna, Spain and is specialized in franchising.

$\mathbf{M}^{\mathbf{a}}$ Teresa García-Álvarez is a Assistant Professor in Business Organization at the University of La Coruna, Spain and works on themes related to the electricity sector, although she has cooperated in data collection.

\section{BIBLIOGRAPHY}

1. Bradach, J. (1998): Franchise Organizations. Harvard Business School Press, Boston.

2. Brickley, J.; Dark, F. \& Weisbach, M. (1991): “An Agency Perspective on Franchising”, Financial Management, vol. 20, spring, pp. 27-35.

3. Cliquet, G. (2000): "Plural Forms in Store Networks: A Model for Store Network Evolution", International Review of Retail Distribution and Consumer Research, vol. 10, pp. 369-387.

4. $\quad$ Dant, R.; Paswan, A. \& Kaufmann, P. (1996): "What we know about Ownership redirection in Franchising: A Meta-Analysis", Journal of Retailing, vol. 72, n 4, pp. 429-444.

5. Lafontaine, F. \& Kaufmann, P. (1994): "The Evolution of Ownership patterns in Franchise Systems", Journal of Retailing, vol. 70, $\mathrm{n}^{\circ}$ 2, pp. 97-113.

6. Oliva, R. (1995): "A Vensim module to calculate summary statistics for historical fit", 〈http://www.sd3.info/models/Library/Misc/TheilStatistics/D4584theil.pdf >

7. Oxenfeldt, A. \& Kelly, A. (1968-69): "Will Successful Franchise Systems Ultimately Become WhollyOwned Chains?", Journal of Retailing, winter, vol. 44, pp. 69-83.

8. Pénard, T.; Raynaud, E. Y Saussier, S. (2003): "Dual distribution and royalty rates in franchised chains: An empirical analysis using French data", Journal of Marketing Channels, vol. 11, pp. 5-31.

9. Rubin, P. (1978): "The theory of the firm and the structure of the franchise contract", Journal of Law and Economics, vol. 21, April, pp. 223-233.

10. Sen, K. C. (1998): "The Use of Franchising as a Growth Strategy by US Restaurant Franchisors", Journal of Consumer Marketing, vol. 15, nº 4, pp. 397-407.

11. Shane, S. (1996): "Hybrid Organizational Arrangements and their Implications for Firm Growth and Survival: A Study of New franchisors", Academy of Management Journal, vol. 39, nº 1, pp. 216-234.

12. Sterman, J. D. (1984): “Appropriate Summary Statistics for Evaluating the Historic Fit of the System Dynamics Models”, Dynamica, vol. 10, pt. II, pp. 51-66.

13. Theil, H. (1966): Applied Economic Forecasting. Amsterdam North Holland Publishing Company.

14. Thompson, R.S. (1992): "Company ownership versus franchising: Issues and evidence", Journal of Economic Studies, vol.

15. Watson, A.; Stanworth, J.; Healeas, S.; Purdy, D. \& Stanworth, C. (2005): "Retail Franchising: An Intellectual Capital Perspective", Journal of Retailing and Consumer Services, vol. 12, pp. 25-34.

16. Yin, X. y Zajac, E. (2004): "The strategy/governance structure fit relationship: Theory and evidence in franchising arrangements", Strategic Management Journal, vol. 25, p. 365-38. 